(cf. cân. 918). Assim, um atraso justificado, ou um contratempo, serão motivos relevantes. Mais uma vez percebe-se a preocupação do legislador com uma eventual banalização do sacramento. De fato, infelizmente há casos de pessoas que querem comungar, mas sem a devida reverência, mantendo uma relação idolátrica ou supersticiosa com o excelso sacramento.

Com relação às espórtulas, vê-se que o legislador procura afastar qualquer identificação com simonia (venda de coisas sagradas). É certo que o ministro faz jus ao sustento oriundo do próprio altar ao qual serve (cf. Mt 10,$10 ; 1$ Cor 9,13 ). Nada obstante, não poderá fazer acepção de pessoas, levando em consideração o poder econômico do fiel. Pe. Jesus Horta sintetiza de forma lapidar o relacionamento justo entre o ministro e os estipêndios:

"O sacerdote deveria dar prova de desprendimento; o ideal seria que ele pudesse dizer, com são Paulo, que não foi gravoso à comunidade." (cf. Os Sacramentos da Igreja na sua Dimensão Canônico-Pastoral, Loyola 1987, pág. 117)

Os cânones comentados neste artigo demonstram a magna solicitude que o legislador tem para com os sacramentos, máxime a Eucaristia. Sem sombra de dúvida, os sacramentos são o inestimável tesouro da Igreja, à qual me referi no início do texto. $\mathrm{O}$ direito canônico não poderia man- ter-se silente a respeito do tema. $\mathrm{O}$ leitor deve ter percebido que o objetivo da regulamentação jurídica não é criar grilhões para a vivência sacramental. Muito pelo contrário. Não houvesse leis claras protegendo o sacramento da Eucaristia, e, muitas vezes, estaríamos todos à mercê do arbítrio de algum ministro incauto ou não teríamos como exigir nosso direito por falta de respaldo explícito.

A Eucaristia é a fonte de nossa vida. Descurar desse sacramento seria um equívoco imperdoável do código. Portanto, o legislador não quis ser omisso. Por fim, é importante ressaltar que o regime jurídico deste sacramento, apesar de estar bem detalhado no código, não se esgota nesse diploma legal. As próprias normas litúrgicas nos oferecem uma importante fonte. Além disso, temos as leis extravagantes e a eventual manifestação do Romano Pontífice a propósito do tema através de motu proprio.

Não se perca de vista o princípio que resume todo labor jurídico no grêmio da Igreja, expresso no adágio latino salus animarum suprema lex est (cf. cân. 1752). Sendo a salvação das almas o grande ideal, o canonista tem a honorável tarefa de criar as condições necessárias, a infra-estrutura, para que tal ordem de coisas se transforme em realidade.

Edson Luiz Sampel é advogado e mestrando em Direito Canônico pelo Instituto de Direito Canônico "Pe. Dr. Giuseppe B. Pegoraro", São Paulo - SP.

\section{A EUCARISTIA ENQUANTO SACRIFÍCIO, CEIA, COMUNHÃO E SOLIDARIEDADE}

\section{Pe. Dr. Valeriano dos Santos Costa}

A Eucaristia é o coração e o ápice da vida e da Liturgia da Igreja, como diz o Catecismo da Igreja Católica:

"A Eucaristia é o coração e o ápice da vida da Igreja, pois nela Cristo associa sua Igreja e todos os seus membros a seu sacrifício de louvor e de ação de graças oferecido uma vez por todas na cruz a seu Pai; pelo seu sacrifício ele derrama as graças da salvação sobre o seu corpo, que é a Igreja"'.

É neste sentido que o Missal Romano afirma que "a celebração da Missa, como ação de Cristo e do povo de Deus hierarquicamente ordenado, constitui o centro de toda a vida cristã para a Igreja universal, para a Igreja local e para cada um dos fiéis"2.

Sabemos que a Eucaristia como o "sacramento dos sacramentos, ou primeiro dos sacramentos, para onde todos os outros se ordenam como para um fim" já era uma síntese bem elaborada, quando o "Doutor Angélico" a formulou de forma tão competente ${ }^{3}$. Na verdade, ao fazer parte dos sacramentos de iniciação, nos indica que o Batismo e a Confirmação somente cumprem plenamente o seu papel, quando o iniciado se senta à mesa eucarística para com toda a comunidade, participar da Ceia do Senhor. Como diz Lopez Martín, na relação de culminância entre Batismo e Eucaristia temos a identidade da Igreja:

"Ingressa-se nessa comunidade por meio do batismo (cf. At. 2,38-41.47), porém o momento culminante que a define é a participação na ceia do Senhor (cf. 1Cor 11,20) ou fração do pão (At 2, 42.46), uma tradição que procede do próprio Cristo e que, misteriosamente, liga os discípulos ao sacrifício de sua morte e ressurreição"4.

${ }^{1}$ Catecismo da Igreja Católica, 1407

${ }^{2}$ IGMR 1

${ }^{3}$ TOMÁS DE AQUINO. Suma Teológica, Terceira Parte, Questões 69-90, COSTA

R. DE BONI LA. (eds.), Caxias do Sul: 1980, p. 4018

${ }^{4}$ LOPEZ MARTíN, Julian. No Espírito e na Verdade, Vol. I, Introdução Teológica à Liturgia, São Paulo: Vozes, 1996, p. 30 
São três as dimensões fundamentais da Eucaristia: $\underline{\text { Sacrifíció, }}$ Ceia-Refeição e Comunhão-solidariedade.

Tentaremos refletir sobre cada um destes aspectos para termos uma visão completa de todo o mistério da Eucaristia.

\section{a) A Eucaristia enquanto Sacrifício}

Não resta dúvida de que o sacrifício é um elemento central do mistério eucarístico, bem como do mistério da Liturgia em si. Na história das religiões não existe culto sem sacrifício.

Segundo Moltmann ${ }^{5}$, partindo do ponto de vista antropológico e da história das religiones em geral, os homens desde sempre pensaram que seu ser foi dado por um poder transcendente. A resposta a esta realidade era o dom de sacrifício de si mesmos na entrega a este poder transcendente. Os cultos religiosos, unidos ao sacrifício, celebravam este auto-oferecimento do homem mediante símbolos reais pars pro toto (esta também é a opinião de todos os autores que tratam da questão do sacrifício nas religiões). A forma originária de todo o sacrifício eram as primícias. Eram sacrifícios de caráter substitutivo. $\mathrm{Na}$ história das religiões é insustentável a idéia de que os homens faziam sacrifícios para conquistar os deuses (do ut des). Isto é uma forma tardia, sobretudo romana pagã. $\mathrm{Na}$ verdade, os sacrifícios colocavam o homem em comunhão festiva com a divindade.

Uma definição completa de sacrifício, no seu amplo sentido litúrgico, nos dá Neunheuser: "Sacrifício é a apresentação feita a Deus (ou a um ser superior) de modo ritual e por um membro da comunidade para isto designado (sacerdote), de um dom concreto (vivo) com o qual o sacrificante se identifica para exprimir a sua autodoação respeitosa, grata e amorosa; com o objetivo de ser com ele transformado em um ser superior (sagrado), por meio da consagração que santifica em virtude da ação divina (originária) presente; e de ficar finalmente unido a Deus, que aceita com benignidade o dom e, por conseguinte, o próprio sacrificante, em plena comunhão de vida e amor".

Desta forma, perguntamo-nos: Como os cristãos chegaram à compreensão sacrifical da Ceia de Cristo? Certamente, os primórdios estão na Páscoa judaica, celebrada fundamentalmente como ceia sacrifical. Desta maneira podemos

${ }^{5}$ Cf. MOlTiMANN, J. El Dios crucificado. La cruz de Cristo como Base y Crítica de toda Teologia Cristiana, Salamanca: Ediciones Sígueme, 1977, 64-65

${ }^{6}$ NEUNHEUSER, B. Sacrificio, in Dicionário de Liturgia, São Paulo: Paulinas/ Paulistas, 1992, 1070-1071 percorrer os seguintes passos, com Salvatore Marsili, que vê a Páscoa hebraica como um símbolo eloqüente da Páscoa de Cristo?:

$\left.1^{\circ}\right)$ Primórdios: Páscoa hebraica como símbolo da Páscoa de Cristo

A celebração da Páscoa hebraica era feita num sacrificio, como memorial da Páscoa-Libertação do Egito, englobando três realidades distintas:

a) o passado = fato histórico;

b) o presente $=$ inclusão da dimensão comunitária e pessoal através do memorial;

c) 0 futuro = dimensão escatológica que fazia da Páscoa hebraica um símbolo da libertação definitiva de toda escravidão. Os cristãos acreditam que é esta a Páscoa consumada com o sacrifício de Cristo.

$\left.2^{\circ}\right) \mathrm{Na}$ estruturação ritual da Páscoa hebraica (tipo da Páscoa de Cristo) foram usados dois ritos sacrificais anteriores ao Exodo:

a) O Cordeiro Pascal, sacrifício da primavera entre as tribos nômades pastoris de Canaã (Ex 12,6; Lv 23,5; Nm 28,16; Dt 16, 1-2).

b) Os Azimos, outro rito da primavera em ambientes agrícolas (sedentários). Tratava-se de pão não fermentado, ou seja, sem nada da colheita anterior (Ex 13,3; Lv 23,6; Nm 28,17; Dt 16, 3ss).

Ambos os «sacrifícios» eram realizados de forma integrada, começando com os sacrifícios de ovelhas e bois e, a seguir, durante sete dias se sacrificavam os pães ázimos, criando assim, a linguagem técnica: sacrificarás a Páscoa (Dt 16ss).

$\left.3^{\circ}\right)$ Cinqüenta dias após o rito de libertação celebrado na véspera da saída do Egito (cordeiro imolado), o Êxodo dos hebreus teve sanção definitiva com o rito do Sacrifício da Aliança nas encostas do Sinai (Ex 24, 1-8). Era o sacrifício da Aliança no sangue promovido para fazer a memória da Páscoa=Libertação do Egito (Ex 19,4-6) .

$4^{\circ}$ ) Para garantir a perpetuidade, a Páscoa hebraica que, portanto, é única e nunca repetível, foram instituídos sacrifícios diários: dois cordeiros (um de manhã e outro à tarde), juntamente com pães para serem queimados como sacrifício de agradável perfume ao Senhor $(\mathrm{Nm} 28,3-8)$. O mesmo se deveria fazer todos os sábados (Nm 28, 9-10). O Levítico fala do sacrifício dos pães da proposição, queimados diariamente ao Senhor na mesa de ouro $(\operatorname{Lv} 24,59)$.

${ }^{7}$ Cf. MARSILI, Salvatore. Teologia da Celebração Eucarística, in AA.VV. A Eucaristia. Teologia História e Celebração, ANAMNESIS 3, São Paulo: Paulinas, 1987, 23 ss.

${ }^{8} \mathrm{Cf}$. Ibid., 141 . 
5) Páscoa real é a Páscoa de Cristo

Os cristãos entenderam que a simbologia do «Servo Sofredor», cordeiro que voluntariamente se sacrifica pela salvação de muitos (Is 53, 12; Lc 22,20) deve ser aplicada a Cristo, cuja Páscoa é um sacrificio perfeito $e$ definitivo, que sela uma «Nova Aliança no sangue» (1 Cor 11,25).

A simbologia bíblica do Servo Sofredor que se deixa imolar pela salvação de muitos tem muitos paralelos com a Paixão sacrifical de Cristo, como podemos constatar:

\begin{tabular}{|c|c|}
\hline $\begin{array}{l}\text { Não tinha beleza que atraísse os olhares } \\
(\text { Os } 53,2)\end{array}$ & Imagem de Cristo torturado \\
\hline Desprezado e abandonado (Is 53,3 ) & $\begin{array}{l}\text { A criada que guardava a porta diz então } \\
\text { a Pedro: "Não és tu também um dos } \\
\text { discípulos deste homem?" Respondeu } \\
\text { ele: "Não sou" (Jo 18,17). Quereis que } \\
\text { eu vos solte o rei do judeus? Então eles } \\
\text { gritaram de novo: "Esse não, mas } \\
\text { Barrabás!". Barrabás era um bandido (Jo } \\
\text { 18,39-40). O povo permanecia, a olhar. } \\
\text { Os chefes, porém zombavam dele (Lo } \\
23,35 \text { ). }\end{array}$ \\
\hline $\begin{array}{l}\text { Foi transpassado por causa das nossas } \\
\text { transgressões (Is } 53,5 \text { ). }\end{array}$ & $\begin{array}{l}\text { Chegando a Jesus e vendo-o já morto, } \\
\text { não lhe quebraram as pernas, mas um } \\
\text { dos soldados traspassou-lhe o lado com } \\
\text { uma lança e imediatamente saiu sangue } \\
\text { e água (Jo 19, 33-34). }\end{array}$ \\
\hline $\begin{array}{l}\text { Maltratado, não abriu a boca; como um } \\
\text { cordeiro conduzido ao matadouro (Is } \\
53,7 \text { ). }\end{array}$ & $\begin{array}{l}\text { Herodes interrogou-o com muitas per- } \\
\text { guntas; Ele, porém nada the respondeu } \\
(\mathrm{Lc} 23,9) \text {. }\end{array}$ \\
\hline $\begin{array}{l}\text { Após detenção e julgamento foi preso e } \\
\text { tirado da terra dos viventes (Is } 53,8 \text { ). }\end{array}$ & $\begin{array}{l}\text { Então a corte, o tribuno e os guardas } \\
\text { dos judeus prenderam a Jesus e o ata- } \\
\text { ram (Jo 18,12)...Tomai-o vós e crucificai- } \\
\text { o, porque eu não encontro culpa nele. } \\
\text { Os judeus responderam: Nós temos uma } \\
\text { Lei e conforme esta Lei ele deve morrer } \\
\text { porque se fez Filho de Deus (Jo 19, 6- } \\
\text { 7). Então eles tomaram a Jesus...o } \\
\text { crucificaram...E inclinando a cabeça, } \\
\text { entregou o espírito (Jo 19,17.18.30). }\end{array}$ \\
\hline
\end{tabular}

132 REVISTADE CULTURATEOLÓGICA
Deram-lhe sepultura entre os ímpios e um túmulo entre os ricos (Is 53,9).

Havia um jardim no lugar onde ele fora crucificado e, no jardim, um sepulcro novo no qual ninguém fora colocado. Ali, então eles depositaram Jesus (Jo 19,41-42).

Tendo sacrificado sua vida pelo pecado, certamente verá uma descendência e por desígnio de Deus há de triunfar (Is 53,10 ).

À tarde desse mesmo dia, o primeiro da semana, estando fechadas as portas onde se achavam os discípulos, por medo dos judeus, Jesus veio e, pondo-se no meio deles, lhes disse: A $\mathrm{Paz}$ esteja convosco... Os discípulos ficaram cheios de alegria por ver o Senhor (Jo 19, 19-20).

Justificará a muitos..Levou sobre si os pecados de muitos (Is 53, 11-12).

Com os fortes repartirá os seus despojos (Is 53, 12). Repartem entre si as minhas vestes e sobre a minha túnica lançam sorte (SI 22, 19).

Pois isto é o meu sangue, sangue da Aliança, derramado por muitos pela remissão dos pecados (Mt 26,28).

Os soldados, quando crucificaram Jesus, tomaram as suas vestes e repartiram... Ora a túnica era sem costura, tecida como uma só peça, de alto a baixo. Disseram entre si: "Não a rasguemos, mas tiremos a sorte para ver com quem ficará" (Jo 19,23-24).

$\left.6^{\circ}\right) \mathrm{Na}$ instituição do ritual da nova Páscoa (ceia e sacrifício), tanto os Sinóticos (Mt 26,26; Mc 14,22; Lc 22,20), como 1Cor 11,23-24 utilizam o rito dos dois momentos pascais (sacrificais dos hebreus), ou seja, o pão e o sangue (vinho), identificando Cristo, que se deu a si próprio como bebida e comida, rituais para a celebração da nova Páscoa, com o verdadeiro Cordeiro que tira o pecado do mundo! Nos Sinóticos, Cristo é identificado com o Cordeiro, «Servo Sofredor», pois seu sangue é derramado "por muitos" para a remissão dos pecados ( $M t$ 26,28; $M c$ 14,24; Lc 22,20). Em Lucas e em 1 Cor 11,23-25 Jesus ordena que o novo rito da Páscoa seja realizado para fazer memória que perpetua o evento único da salvação que é a sua Paixão-Morte-Ressurreição. 
Na carta aos Coríntios", São Paulo põe em paralelo a Ceia do Senhor, como sacrifício da Comunhão no altar de Cristo, e a ceia das carnes sacrificadas aos ídolos, como sacrifício do altar dos demônios. Portanto, para a Igreja primitiva, a Ceia Eucarística (fração do pão) estava intimamente ligada ao Sacrifício da Cruz. Foi Cristo mesmo quem a instituiu durante uma Ceia Pascal judaica ${ }^{10}$. Como diz Giacinto Padoin, a tipologia bíblica da última ceia de Jesus faz dela "uma transposição do banquete da páscoa antiga, com as suas estruturas rituais, as suas categorias expressivas, o significado de salvação e o valor de memorial amplamente acolhido"'1!

$7^{\circ}$ ) O novo rito da Páscoa passa a ser rapidamente celebrado entre os primeiros cristãos com o nome de «fração do pão» (ICor 10,16-17; Lc 24,30.35; At 2, 42.46; 20,7.11). Desta maneira, da Ceia Eucarística dos primeiros cristãos, podemos extrair três aspectos importantes relacionados com a Nova Páscoa:

\section{Cor $10,14-22$}

${ }^{10}$ Sabemos que existem divergências quanto à identificação da Ceia de Jesus como Ceia Pascal. Para mim esta questão já está superada. Joaquim Jeremias enumera dez motivos para frisar que a ceia de Jesus era uma ceia pascal: 1) A última ceia teve lugar em Jerusalém. 2) Ela foi celebrada durante a noite (cf. Jo 13,30; 1Cor 11,23); e isto não acontecia nunca, a não ser para a celebraçã̃o pascal. 3) Jesus estava apenas em companhia dos doze apóstolos. Este fato deu-se exclusivamente neste dia; habitualmente Jesus tomava suas refeições rodeado por todos aqueles que o queriam ouvir. 4) Jesus estava reclinado sobre a mesa (Jo 13,12.23.24-25; Mc 14,18), enquanto costumava, noutras ocasiões, comer sentado. Isto era um sinal da Páscoa, a noite da libertação. 5) Ele partiu o pão durante a ceia, e não no início dela, o que era outro indício da Páscoa, pois esta última era antecipada de uma entrada ritual. 6) Ele bebeu vinho: isto acontecia nas festas e era de obrigação na festa da Páscoa. 7) A ceia se concluiu com um hino de Ação de Graças, o "Hallel" pascal (Mc 14,26; Mt $26,30)$.

8) Após a ceia Jesus não voltou para Betânia, mas encaminhou-se diretamente para o Horto das Oliveiras. Durante a noite pascal era de obrigação pernoitar em Jerusalém. Para isto o perímetro da cidade era esticado até Betfagé, pois havia na cidade cerca de cem mil pessoas. 9) $O$ anúncio da sua iminente paixão estava inserido na ceia como "haggaddà", interpretação dos elementos do banquete que era parte integrante do rito da Páscoa. 10) A interpretação de Jesus restringe-se ao pão e ao vinho, e se refere não ao passado, mas ao presente e ao futuro; Cf. JEREMIAS, Joaquim. Le parole dell'ultima cena, Paidéia, 1973, 43-70; citado por PADOIN, Giacinto. O Pão que Eu Darei... O Sacramento da Eucaristia, São Paulo: Paulinas, 1999, 18.

$"$ PADOIN, Giacinto. Op. Cit., 34 a) Uma celebração convival e comunitária

b) Um banquete sagrado para a unificação do Corpo de Cristo

c) Um banquete nitidamente sacrifical

$8^{\circ}$ ) Os Padres da Patrística ${ }^{12}$ fizeram da Eucaristia uma leitura em duas chaves: em tipologia pascal e em chave mistérica da presença da paixãomorte de Cristo:

a) Em tipologia pascal: A primeira alusão explícita à leitura pascal da morte de Cristo é 1Cor 5,7 ( \pm 57 d.C.). No fim do primeiro século, com a redação do $4^{\circ}$ evangelho, a morte de Cristo assume uma dimensão claramente pascal desde a sua $1^{\text {a }}$ aparição: "O cordeiro de Deus que tira o pecado do mundo" (Jo 1,29.36), até à sua última aparição, quando morre na cruz no mesmo horário em que se sacrificavam os cordeiros no templo: "Nenhum osso lhe será quebrado" (Jo 19,36). Por isso, na literatura patrística, a celebração da Ceia Eucarística passou a ser chamada de Páscoa dominical, anual ou diária ${ }^{13}$.

b) Em chave mistérica da presença paixão-morte de Cristo: Na Patrística, a Eucaristia como sacrifício ritual do acontecimento histórico da paixão-morte de Cristo foi lida através da teologia da imagem, símbolo, tipo, sacramento e mistério. Porém, para a literatura patrística, estes termos não têm o significado que thes damos hoje. Todos trazem em si a «força da realidade», em oposição ao vazio e semivazio das sombras da realidade. Como diz o autor da Carta aos hebreus: "A lei tinha apenas as sombras das realidades futuras, não a imagem das realidades acontecidas" (Hb 10,1). Uma oração litúrgica diz: "Hoje, Senhor, apresentamos a ti a nossa devoção, porque é o dia no qual nasceu o cordeiro imolado, cuja imagem imolamos"14.

$\left.9^{\circ}\right)$ Esta fé litúrgica erigida pela Patrística permanece sem grandes problemas até a virada do primeiro milênio, que foi marcado pelas «controvérsias eucarísticas», enquanto o primeiro milênio tinha sido marcado pelas «contro-

${ }^{12}$ Grandes figuras da Teologia e da Mística da Igreja dos primeiros séculos até o século VI. O último grande padre foi Gregório Magno Papa (590-604)

${ }^{13}$ Cf. EUSÉBIO DE CESARÉIA. De Solemnitate Paschali, 7; 12; DIDIMO. De Trinitate, 3,21; JOÃO CRISÓSTOMO. In Tim Hom, 5,3; Ad Judaeos, 3,43 ; EFRÉM SÍRIO. Sermo in Hebdom Sanctam, 2,20; GREGÓRIO NANZIAZENO. In S. Pascham Oratio, 40, 30; JERÔNIMO. In Ezech., 12,1 ; AGOSTINHO. Contra litteras Pitiliani, 2,37; PAULINO DE NOLA. Carmina 27,53-59

14 Sacram. Bergomense, Bérgamo: ed. Paredi, 1962, 63 
vérsias batismais». Na verdade, os primeiros sinais vieram no século IX com Amalário de Metz que, buscando explicações plausíveis da Eucaristia, descobriu e consagrou o método alegórico. Neste sistema, Amalário inventou a doutrina do corpus triforme de Cristo $^{15}$.

\section{B) A Eucaristia enquanto Ceia}

A Eucaristia tem suas raízes na Ceia Pascal judaica, como já foi dito anteriormente. Foi durante a celebração desta ceia que Jesus instituiu a Páscoa da Nova Aliança. O mestre disse: Ide preparar-nos a Páscoa para comermos (Lc 22,8)... Quando chegou a hora, ele pôs-se à mesa com seus apóstolos e disse-lhes: "Desejei ardentemente comer esta páscoa convosco antes de sofrer, pois digo que não a comerei até que ela se cumpra no Reino de Deus" (Lc 22, 14-16).

A celebração da Páscoa judaica é um rito em forma de ceia, inaugurado por Moisés para comemorar, antecipadamente, o Exxodo do dia seguinte em busca da terra prometida. Antes de realizar o seu Êxodo, como volta para o Pai, Jesus reuniu os seus numa ceia pascal para comemorar, antecipadamente, o dia seguinte. Portanto a Eucaristia é ritualmente uma ceia convivial e sagrada.

$\mathrm{Na}$ verdade, toda a conversa em torno de uma mesa posta é uma ação de graças pelo convite, a comida e a presença dos amigos. Na mesa eucarística esta ação de graças predomina de tal maneira, que a reunião da fração do pão é chamada de Eucaristia, ou seja, «ação de graças».

O rito da ceia está intimamente ligado ao comer. Jesus se dá para ser comida

${ }^{15}$ Durante a Missa, o sacerdote parte o corpo de Cristo em três pedaços, colocando uma no cálice. Para Amalário, a parte da hóstia colocada no cálice representa o corpo de Jesus nascido de Maria Virgem, a parte que é comungada pelos fiéis é o corpo místico de Cristo, e a parte que se conserva, o conjunto dos defuntos $\mathrm{Cf}$. CATTANEO, E. Il culto cristiano in Occidente. Note Storiche, Roma: Edizione Liturgiche, 1992, 174 ; (Cf Liber Officialis, 3, c, 35 (PL, 105, 1154-1155). Embora Amalário tenha sido condenado em 838 no Concílio de Quiertzy, a teologia alegorizante do corpus triforme seguiu avante durante a Idade Média. Porém, o que caracteriza o alegorismo é sua falta de rigor científico, como podemos interpretar das palavras de Lubac: "A vrai dire, elles ne requièrent pas d'autres explications que la fantasie de leurs auteurs...Chacun peut y exercer une liberté que rappelle celle des anciens Grecs par rapport à leurs mythes"; LUBAC, H. DE. Corpus Mysticum. L'Eucharistie et l'Église au Moyen Âge, Paris: Éditons Montagne, 1948, 333s e bebida a fim de que possamos ter vida plena (Jo 6). Por isso, o Missal Romano diz a respeito do pão, como sinal sensivel da Eucaristia:

"A verdade do sinal exige que a Matéria da Celebração Eucarística pareça realmente um alimento. Convém, portanto, que, embora ázimo e com a forma tradicional, seja o pão eucarístico de tal modo preparado que o sacerdote, na Missa com o povo, possa de fato partir a hóstia em diversas partes e distribuí-las ao menos a alguns fiéis.... O gesto, porém, da fração do pão, que por si só designava a Eucaristia nos tempos apostólicos, manifestará mais claramente o valor e a importância do sinal da unidade de todos num só pão, e da caridade fraterna pelo fato de um único pão ser repartido entre os irmãos (IGMR 283).

O convite para comer o Pão da Vida abole para sempre a proibição da Primeira Criação de não se comer do fruto da árvore do conhecimento:

Iaweh Deus plantou um jardim no oriente, e aí colocou o homem que modelara. Iaweh Deus fez crescer do solo toda espécie de árvores frondosas de ver e boas de comer, e a árvore da vida no meio do jardim, e a árvore do conhecimento do bem e do mal (Gn 2, 8-9)... E Iaweh Deus deu ao homem este mandamento: "Podes comer de todas as árvores do jardim. Mas da árvore do conhecimento do bem e do mal não comerás, porque no dia em que dela comeres terás que morrer (Gn 2, 17).

$\mathrm{Na}$ história das religiões, segundo Mircea Eliade, encontramos o "mito da árvore da vida" plantada no centro do Cosmos, como "protótipo de todas as plantas miraculosas, as que ressuscitam os mortos, as que curam os doentes; as que dão juventude etc." ${ }^{\prime 16}$.

Sabemos que na tradição cristã a cruz está plantada no centro da terra (Calvário) e constitui-se como "árvore da vida", "fonte da imortalidade" e "sustentáculo do mundo" 17 . Interessante é notar que na proibição divina somente a árvore do conhecimento está incluída na ameaça de morte. "A serpente

${ }^{16}$ ELIADE, Mircea. Tratado de História das Religiões, São Paulo: Martins Fontes, 1993, 236

17 "Quapropter lignum crucis coeli sustinit machinam, terrae fundamenta corroborat, adfixos sibi homines ducit ad vitam"; FIRMICUS MATERNUS 27,1, citado por ELIADE, Mircea, Tratado..., 237 
constitui o obstáculo com que esbarra o homem na sua busca da fonte da imortalidade, da Árvore da Vida"18.

O capítulo VI de São João aponta para uma direção contrária à do Gênesis em relação à árvore do conhecimento. $\mathrm{O}$ que predomina na Nova Criação não é mais a árvore do conhecimento do Bem e do Mal, mas a Árvore da Vida, transformada sacramentalmente em Pão da Vida e Cálice da Salvação. Daí a ordem explícita: Comei e bebei.. Portanto, o sacrifício de Cristo venceu a serpente e nos dá acesso ao alimento da imortalidade.

\section{Da multiplicação dos pães à Ceia do Senhor}

A bênção de Jesus na Ưltima Ceia tem elementos da bênção dada anteriormente na multiplicação dos pães: tomou o pão, elevou os olhos para o céu, deu graças, partiu-o e repartiu-o entre os seus. São gestos litúrgicos, profundamente ligados à ceia, com convidados e comensais, o que o judeu não fazia sem a bênção e ação de graças:

\begin{tabular}{|c|c|c|c|}
\hline Mc 6, 41-42 & Mt 14,19 & Lc 9, 16 & Jo 6,11 \\
\hline $\begin{array}{l}\text { tomando os } \\
\text { cinco pães e } \\
\text { os dois peixes, } \\
\text { elevou os olhos } \\
\text { ao céu }\end{array}$ & $\begin{array}{l}\text { tomou os cinco } \\
\text { pães e os dois } \\
\text { peixes. Elevou } \\
\text { os olhos ao céu }\end{array}$ & $\begin{array}{l}\text { tomando os cinco } \\
\text { pães e dois peixes, } \\
\text { ele elevou os olhos } \\
\text { para o céu }\end{array}$ & $\begin{array}{l}\text { tomou, então, } \\
\text { Jesus os pães, }\end{array}$ \\
\hline $\begin{array}{l}\text { abençoou, partiu } \\
\text { os pães e os deu } \\
\text { aos discípulos } \\
\text { para que lhes } \\
\text { distribuíssem }\end{array}$ & $\begin{array}{l}\text { e abençoou. Par- } \\
\text { tindo os pães, } \\
\text { deu-os aos discí- } \\
\text { pulos e os discí- } \\
\text { pulos às multi- } \\
\text { dões }\end{array}$ & $\begin{array}{l}\text { Os abençoou, } \\
\text { partiu-os e deu } \\
\text { aos discípulos } \\
\text { para que os dis- } \\
\text { tribuíssem à mul- } \\
\text { tidão }\end{array}$ & $\begin{array}{l}\text { E, depois de } \\
\text { dar graças, dis- } \\
\text { tribuiu-os aos } \\
\text { presentes, as- } \\
\text { sim como os } \\
\text { peixinhos }\end{array}$ \\
\hline
\end{tabular}

${ }^{18}$ ELIADE, Mircea. Op. Cit., 232-233
Instituição da Eucaristia

\begin{tabular}{|c|c|c|c|}
\hline 1 Cor 23,23 & Mc $14,22-25$ & Lc $22,19-20$ & Mt $26,26-28$ \\
\hline $\begin{array}{l}\text { O Senhor Jesus } \\
\text { tomou o pão e, } \\
\text { depois de dar gra- } \\
\text { ças, partiu-o e } \\
\text { disse: isto é o } \\
\text { meu corpo que é } \\
\text { para vós. Fazei } \\
\text { isto em memória } \\
\text { de mim. Do } \\
\text { mesmo modo, } \\
\text { após a ceia, to- } \\
\text { mou o cálice, di- } \\
\text { zendo: Este cáli- } \\
\text { ce é a nova Ali- } \\
\text { ança no meu san- } \\
\text { gue. }\end{array}$ & $\begin{array}{l}\text { Enquanto comiam, } \\
\text { ele tomou o pão } \\
\text { partiu-o e distri- } \\
\text { buiu-lhes, dizendo: } \\
\text { Tomai, isto é o } \\
\text { meu corpo. Tomou } \\
\text { o cálice e dando } \\
\text { graças, deu-lhes e } \\
\text { todos beberam. } \\
\text { Disse-lhes. Isto é o } \\
\text { meu sangue. }\end{array}$ & $\begin{array}{l}\text { e tomou um pão, } \\
\text { deu graças partiu- } \\
\text { o distribuiu-o a } \\
\text { eles dizendo: isto é } \\
\text { o meu corpo que é } \\
\text { dado por vós. Fazei } \\
\text { isto em minha } \\
\text { memória. E depois } \\
\text { de comer fez o } \\
\text { mesmo com o cá- } \\
\text { lice, dizendo: este } \\
\text { é o cálice da nova } \\
\text { aliança. }\end{array}$ & $\begin{array}{l}\text { enquanto comi- } \\
\text { am, Jesus tomou } \\
\text { o pão e tendo-o } \\
\text { abençoado par- } \\
\text { tiu-o e, distribu- } \\
\text { indo aos seus } \\
\text { discípulos disse: } \\
\text { tomai e comei } \\
\text { isto é o meu cor- } \\
\text { po; depois to- } \\
\text { mou o cálice e, } \\
\text { dando graças, } \\
\text { deu-lhes, dizen- } \\
\text { do: bebei dele } \\
\text { todos, pois isto é } \\
\text { o meu sangue, o } \\
\text { sangue da nova } \\
\text { aliança. }\end{array}$ \\
\hline
\end{tabular}

Tomou: Tomar significa o conjunto de nossas ações cotidianas e também as solenes, como tomar posse de um cargo. Já que o termo aparece quatro vezes, devemos compreender que o Novo Testamento quis dar-lhe um sentido sacerdotal e solene.

O Pão: Símbolo da existência humana: Comerás o pão com o suor da tua fronte $(\mathrm{Gn} 3,19)$. A partir de agora a existência humana passa a depender de Cristo: Eu sou o pão da vida (Jo 6, 35).

O Cálice: significa a vida como um todo no seu aspecto mais profundo, como diz o salmo: Quão precioso é o meu cálice inebriante (S1 22,5); Tomarei o cálice da Salvação (S1 115,13). Se não comerdes a minha carne e não beberdes o meu sangue, não tereis a vida em vós (Jo 6,53).

Em suas mãos: As mãos de Jesus curam (Lc 4,40; Jo 9, 6ss; Mt 8, 2325; Mc 7, 33 Lc 13,13), compadecem-se e tocam (Mt 1,41), ressuscitam os mortos (Lc 7,14; Mc 5,41). Enfim, as mãos de Jesus dão vida. As mãos de Jesus salvam Pedro que se afogava (Mt 14,31). São também as mãos que alimentam e saciam a fome: Abres as mãos e sacias todo o ser vivo à vontade (S1 145, 16). 
Elevou os olhos: A ti levanto meus olhos, a ti que habitas no céu (S1 123, 1). Em ti esperam os olhos de todos, e no tempo certo tu lhe dás o alimento (S1 145, 15). O pecado de Adão não deixou mais o homem olhar para Deus. Era como a mulher recurvada que não podia olhar para cima (Lc 13,11). Finalmente, o Mistério Pascal celebrado na Eucaristia, possibilita que o homem possa olhar para Deus, como aconteceu com os discípulos de Emaús : Então seus olhos se abriram e eles o reconheceram (Lc 24,31).

Deu graças: Eu te louvo, ó Pai, Senhor do céu e da terra, porque ocultaste estas coisas aos sábios e doutores e as revelaste aos pequeninos. Sim Pai, porque assim foi do teu agrado. Tudo me foi entregue por meu Pai, e ninguém conhece o Filho, senão o Pai, e ninguém conhece o Pai, senão aquele a quem o Filho quiser revelar (Mt 11, 25-27).

Partiu o pão: Rito familiar da partilha do pão se transforma em rito litúrgico da fração do Pão na Eucaristia (At 2, 42; 2,46; 20,7). Símbolo da unidade: Há um só pão, um só corpo, embora sejamos muitos (1Cor 1,17).

Deu o Pão: Está ligado ao gesto do comer. Assim se diz de Eva: Ela colheu o fruto e comeu-o e deu-o ao seu marido $(\mathrm{Gn} 3,6)$. Mas tratava-se do fruto do pecado. Agora se trata do pão da vida.

Aos seus discípulos: Partilhar algo como comida é assumir o companheirismo mais profundo no relacionamento humano. Jesus nos considera amigos e companheiros. É um entrelaçamento de vidas: Quem me come viverá por mim (Jo 6, 57).

Meu corpo: $O$ corpo é o ser humano na sua integralidade. O corpo de Jesus era o seu ser integral. É o corpo de Jesus martirizado e glorificado.

A primeira grande dimensão que se ressalta da Eucaristia como Ceia e refeição é o seu caráter comunitário e de Comunhão, lembrando aqui que a comunhão sacramental com Cristo nos direciona para comunhão com irmãos pelo testemunho da vida cristã. A este respeito, a recente Carta Apostólica Dies Domini (DD) lembra:

"Este aspecto comunitário exprime-se de modo especial no caráter de banquete pascal, que é típico da Eucaristia, onde o próprio Cristo se faz alimento. Por isso, a Igreja recomenda que os fiéis comunguem quando participam da Eucaristia, desde que se encontrem nas devidas disposições. O convite à comunhão eucarística torna-se particularmente insistente, como é óbvio, por ocasião da Missa nos domingos e outros dias festivos" (DD 44).
Por isso, a celebração eucarística deve ser "jubilosa e animada" (DD 50), cativante e participada (DD 51). Recomenda-se muito vivamente aquela mais perfeita participação na missa, pela qual os fiéis, depois da comunhão do sacerdote, recebem do mesmo sacrifício do Corpo do Senhor (SC 55).

O afastamento da assembléia dominical e, por conseguinte, da comunhão, é bastante antigo. Basta conferir o que diz a Carta aos Hebreus: Não deixemos as nossas assembléias, como alguns costumam fazer. Procuremos, antes, animar-nos sempre mais à medida que vedes o dia do Senhor se aproximar $(\mathrm{Hb} 10,25)$. Sant'Inácio de Antioquia é ainda muito mais severo em julgar os ausentes da assembléia dominical: "Não tenteis fazer passar por razoável vossa obstinação de permanecer à parte, mas vinde à reunião geral: que não haja senão uma só oração, uma só súplica, um só espírito, uma só esperança na caridade, na alegria irrepreensivel. Quem não vem à reunião comum torna-se orgulhoso e é juiz de si mesmo, pois está escrito: Deus resiste aos orgulhosos"19.

A primeira punição formal contra a ausência da Assembléia dominical se encontra no cânon 21 do Concílio de Elvira (ano 305, portanto antes da paz constantiniana), onde se previa após três ausências consecutivas uma pena de exclusão temporária da Comunidade ${ }^{20}$.

Outro dado importante a respeito da comunhão são as controvérsias eucarísticas que brotaram no século XI e culminaram com a Reforma Protestante no século XVI. Portanto, o primeiro milênio foi marcado por uma certa tranqüilidade em relação à fé eucarística. A Igreja defendeu a presença real, o que naturalmente tinha que ser. Porém, os séculos seguintes trouxeram um verdadeiro «despertar eucarístico», baseado na teologia da presença real de Cristo na Eucaristia. Isto deu aos teólogos matéria para estudar esta presença real escondida e contida sob o véu do sacramento.

No campo da espiritualidade eucarística, despontou a devoção de ver na hóstia consagrada esta presença escondida de Cristo. Para muitos, ver a hóstia passou a ser o centro da celebração eucarística. Se isto trouxe um afastamento da comunhão, não podemos ficar satisfeitos. Ver a hóstia, como fazemos na elevação eucarística (rito introduzido no século XII) deve nos estimular o fervor para realizar uma boa comunhão e nos envolver mais intimamente com o mistério de Cristo.

${ }^{19}$ Cf. JUNGMANN, J.A. La Liturgie des Premiers Siècles..., 267

${ }^{20}$ Cf. JUNGMANN. Ibid., 267 
Pensando no valor fundamental da Eucaristia como Ceia=Comunhão, temos que evitar duas tendências que prejudicam a participação:

- O purismo, baseado em conceitos vétero-testamentários, que começou a partir do século IV a afastar as pessoas da comunhão. Já dizia S. João Crisóstomo: "Em vão se celebra o sacrifício todos os dias; em vão estamos todos os dias no altar; ninguém vem comungar"21. Isso contrasta com o costume dos primeiros séculos de não se contentar com a comunhão dominical, mas de se levar o pão consagrado para casa, a fim de tomá-lo antes de qualquer refeição.

- A substituição da comunhão pela audiência à missa, o que pode relegar a dimensão convivial da Ceia do Senhor a um plano secundário. A preocupação central do Concílio Vaticano II, no que toca à reforma litúrgica, é "que todos os fiéis sejam levados àquela plena, cônscia e ativa participação das celebrações litúrgicas que a própria natureza da Liturgia exige e à qual, por força do batismo, o povo cristão, «geração escolhida, sacerdócio régio, gente santa, povo de conquista (1Pd 2,9; cf. 2,4-5)》, tem direito e obrigação"22.

$\mathrm{Na}$ Idade Média foi-se notando com o passar do tempo um aumento do número de missas e uma diminuição da freqüência dos fiéis não só à comunhão, mas à própria missa. Aumentava, concomitantemente, o número do clero em cada diocese e, certamente diminuía o nível de formação. A diocese de Constança, por exemplo, na Alemanha, no século XV chegou a ter 17.000 sacerdotes, sendo que apenas 4.700 tinham formação universitária ${ }^{23}$.

Perdendo, aos poucos, a ênfase na dimensão de Ceia=Refeição, a Eucaristia pode se tornar uma devoção em si mesma. $\mathrm{O}$ ano litúrgico deixaria de ser o centro do mistério pascal celebrado. $\mathrm{Na}$ história, constatamos algo semelhante quando a missa virou mais uma devoção do que uma ação celebrada para perpetuar o Mistério de Cristo, de tal forma que ninguém ficou fora do evento único que trouxe a reconciliação da humanidade com Deus, consigo mesma e com todo o Cosmos. Desta forma, a Missa passou também a ser vista mais em função dos seus frutos de interesses pessoais imediatos, criando-se o costume, às vezes, dispendioso de se mandar celebrá-la conforme as necessi-

\footnotetext{
${ }^{21}$ JOÃO CRISÓSTOMO. In Ephs, Hom. 3,4

${ }^{22} \mathrm{SC} 14$

${ }^{23}$ Cf. TÜCHLE G. A reforma e contra-reforma, in: ROGIER L.-J. (dir.) et al. Nova

História da Igreja, vol 3, Petrópolis: Vozes, 1983, 19
}

dades do mandante. Por exemplo, uma série de 7 missas gregorianas exigia 50 velas (de $34 \mathrm{~cm}$ ), 50 moedas e 50 esmolas. E quando alguém mandasse rezar 30 tinha mais despesas, mas também resultados mais seguros:

"Quem cantar ou mandar celebrar 30 dessas missas na ordem assinalada, seja para si, seja a um amigo ou ocasião de qualquer tribulação ou enfermidade, dentro de 30 dias ficará livre. É coisa experimentada"24.

Para responder às necessidades econômicas de um clero numeroso e bastante pobre, praticaram-se anomalias litúrgicas como a missa $\operatorname{seca}^{25}$ e as missas bi-tri-quadrifaciadas ${ }^{26}$

A fim de defender o sentido da Ceia do Senhor, como pão para ser recebido, e condenar muitos abusos litúrgicos se insurgem os reformadores Lutero, Zwínglio e Calvino. Porém, eles entraram em outros detalhes de domínio dogmático que os afastaram do conteúdo católico da Eucaristia, sobretudo do dogma da transubstanciação e da fé na permanência da presença real de Cristo nas espécies consagradas.

Para responder aos Reformadores, foi convocado o Concílio de Trento (1545-1563), o qual dedicou muito espaço à Eucaristia. Embora a participação na Eucaristia e a sua valorização como Ceia-Comunhão não tenha dado muitos passos, Trento trouxe enormes avanços para a teologia eucarística. Foi o Concílio que deu a resposta teológica à questão da unicidade do sacrifício de Cristo e sua relação com a Ceia do Senhor. A multiplicação das Missas "não repete" o sacrifício de Cristo, que é único e nunca repetível (Hb 7,27; 9,12.14.26; $10,10)$, mas perpetua até o fím da História esse evento de salvação ( $u t$ dilectae sponsae suae Ecclesiae visibile \{sicut hominum natura exigit\} relinqueret sacrificium, quo cruentum illud semel in cruce peragendum repraesentaretur eiusque memoria in finem usque saeculi permaneret ${ }^{27}$ ).

${ }^{24}$ FRANZ A. Die Messe im deutschen Mittealter, 1902, 269

${ }^{25}$ Para burlar a proibição de uma só missa por padre ao dia, começaram a se fazer as tais missas secas com o objetivo de colher ofertas. Na verdade não eram missas, mas liturgias da Palavra (sem ofertório, consagração e comunhão). Foram chamadas de Missas porque no momento da consagração se levantava uma hóstia já consagrada anteriormente.

${ }^{26}$ Estas missas, na verdade eram um plágio de várias missas, porém diversificadas até o Ofertório, mas unificadas numa só Oração Eucarística, a partir do Prefácio, portanto. ${ }^{27}$ DS 1740 
Os estudos sobre o memorial hebraico ajudaram a clarear o mistério da Eucaristia, enquanto celebração do Mistério de Cristo.

O Concílio Vaticano II, ao refletir e explicitar o que Trento afirma sobre o Mistério da Eucaristia, une as dimensões de sacrifício e ceia-comunhãosolidariedade inseparavelmente no evento único da salvação:

"Na Última Ceia, na noite que foi entregue, nosso Salvador instituiu o Sacrifício Eucarístico de Seu Corpo e Sangue. Por ele, perpetua pelos séculos, até que volte, o Sacrifício da Cruz, confiando destarte à Igreja, sua Dileta Esposa, o memorial da Sua Morte e Ressurreição: sacramento de piedade, sinal de unidade, vínculo da caridade, banquete pascal em que Cristo nos é comunicado em alimento, o espírito é repleto de graça e nos é dado o penhor da futura glória"28

Como sabemos, o Vaticano II foi uma fantástica tentativa de resgatar a Liturgia, trazendo para a celebração da Eucaristia o seu aspecto de participação comunitária, o que é fundamental no rito da Ceia.

\section{C) A EuCARISTIA ENQUANTo COMUNHÃO-SOLIDARIEDADE}

$\mathrm{O}$ aspecto convivial da Ceia Eucarística nos remete ao compromisso da caridade e da solidariedade com todo o Cosmo. Várias orações do Missal Romano, sobretudo depois da Comunhão, colocam a caridade como o primeiro fruto da Eucaristia. Numa oração temos como fruto da celebração do memorial permanente da paixão de Cristo, o dom da inefável caridade ${ }^{29}$. Em outra oração o crescimento na caridade é o fruto desejado por quem participa do Memorial do Senhor ${ }^{30}$. Temos também uma relação interessante do papel do Espírito Santo que nos é dado na Comunhão: faz-nos perseverar na sinceridade do amor ${ }^{31}$. A oração depois da Comunhão, na Missa do Sagrado Coração de Jesus, é exemplar ao chamar a Eucaristia de Sacramento da caridade:

Ó Deus, que este sacramento da caridade

Nos inflame em vosso amor

E, sempre voltados para o vosso Filho,

Aprendamos a reconhecê-lo em cada irmão.

${ }^{28} \mathrm{SC} 47$

${ }^{29}$ Missal Romano, $17^{\circ}$ Domingo do Tempo Comum, Depois da Comunhão

${ }^{30} 33^{\circ}$ Domingo do Tempo Comum, Depois da Comunhão

$3132^{\circ}$ Domingo do Tempo Comum, Depois da Comunhão
Desta forma, podemos entender que, negligenciando a comunhão sacramental, negligencia-se também a comunhão com os irmãos.

Por isso, participar é muito mais do que ouvir a Missa. Um documento do século XIV, chamado Summula Raymundi afirma que "se alguém ouvir dignamente ainda que uma só missa terá muito mais vantagem do que distribuir aos pobres todos os seus bens"32. Sabemos que a refeição de Deus é a refeição da fraternidade, como diz a Escritura: Quando deres uma festa, chama pobres, estropiados, coxos, cegos (Lc 24, 23)... Feliz quem tomar refeição no Reino de Deus (Lc 14,15).

Finalizamos com as palavras do Santo Padre em seu recente documento sobre a santificação do domingo (Dies Domini):

"Além disso, é importante ganhar uma viva consciência de quanto a comunhão com Cristo está profundamente ligada à comunhão com os irmãos. A assembléia eucarística dominical é um acontecimento de fraternidade, que a celebração deve justamente fazer ressaltar, embora no respeito do estilo próprio da ação litúrgica" (DD 44).

\section{BIBLIOGRAFIA}

AA.VV. Expressão e Experiência de Fé no Culto, in Concilium 82 (1973)2

BARAÚNA, Guilherme. A Sagrada Liturgia Renovada pelo Concilio, Estudos e comentários em torno da Constituição Litúrgica do Vaticano II, Petrópolis: Vozes, 1964.

BARROS, Marcelo. Celebrar o Deus da Vida, São Paulo: Paulus, 1992

BOROBIO, Dionisio (dir.). A Celebração na Igreja.Liturgia $e$ Sacramentologia Fundamental, Vols. I e II, São Paulo: Loyola, 1993.

CASTILlo, J. M. Simbolos de Liberdad. Teologia de los Sacramentos, Salamanca: Ediciones Sígueme, 1981.

CAZELLES, H. \& COTHENET, E. Sacrificio en la Biblia, in POUPARD, $P$. (dir.). Dicionário de las Religiones, Barcelona: Editorial Herder, 1987, 1568-1571

CELAM. Liturgia para a América Latina, São Paulo: Paulinas, 1977

CHAUVET, Luis-Marie. Du Symbolique au Symbole. Essai sur les Sacrements, Paris: Les Éditions du Cerf, 1979

CNBB. Por um Novo Impulso à Vida Litúrgica, São Paulo: Paulinas, 1988

CORBON, Jean. Liturgia de Fonte, São Paulo: Paulinas, 1981

${ }^{32}$ Citado por FRANZ A., Die Messe im deutschen Mittealter, 1902, 103 
DENZINGER-SCHÖNMETZER. Enchiridion Symbolorum definitionum et Declarationum de Rebus Fidei et Morum, editio XXXVI emendata, Barcelona: Herder 1973

HADDAD, A. Eucaristia e Compromisso Social. Como Paulo VI entendeu a Eucaristia na Igreja e na Sociedade, São Paulo: Loyola, 1985

JUNGMANN, Josef A. Liturgie des Premiers Siècles jusqu'à l'époque de Gregoire le Grand, Paris: Lés Éditions du Cerf, 1962

LA BROSSE, O. Rito, in Diccionario del Cristianismo, Barcelona : Editorial Herder, 1986

LEBABE, J. Sacrificio en Grecia, in: POUPARD P. (dir.), Dicionário de las Religiones, Barcelona: Editorial Herder, 1987, 1566-1567

LÉCUYER, J. Le Célébrant. Approfondissement Théologique de sa Tradition, in: $L M D 61$ (1960), 4-29

LODI, Enzo. Liturgia della Chiesa. Guida allo Studio della Liturgia nelle sue Fonti Antiche e Recenti, Bologna: Edizioni Dehoniane, 1981

LÓPES MARTÍN, Julian. No Espírito e na Verdade, Vol. I. Introdução à Teologia Litúrgica, Petrópolis: Vozes, 1996; Vol II. Introdução Antropológica à Liturgia, Petrópolis: Vozes, 1997.

MIRCEA, Eliade. Tratado de História das Religiões, Lisboa: Cosmos, 1990

MAGGIANI, Silvano. Ritos/Ritos, in Dicionário de Liturgia, São Paulo: Lisboa: Paulinas-Paulistas, 1992, 1021-1028

MACKENZIE, J. L. Sacrificio, in Dicionário Bíblico, São Paulo: Paulinas, $1984,819-824$

MARSILI, Salvatore. A Eucaristia. Teologia e História da Celebração, São Paulo: Paulinas, 1986, (Anamnesis 3)

MARTIMORT, Aimé Georges. A Igreja em Oração. Introdução à Liturgia, Petrópolis: Vozes; Vol II, CABIÉ ROBERT. A Eucaristia, 1989; Vol. III, AA.VV. Os Sacramentos

MIRCEA, Eliade. Tratado de História das Religiões, Lisboa: Cosmos, 1990 MURRAY, P. A Linguagem do Culto Cristão, in: Concilium 52 (1970)2, 247-249 NEUNHEUSER, B. L'Eucharistie au Moyen Âge et a l'Époque Moderne, Paris: Les Éditions du Cerf, 1966 (Histoire des Dogmes 4)

ID., Sacrifício, in Dicionário de Liturgia, São Paulo: Paulinas-Paulistas, 1992, 1069-1083
PADOIN, Giacinto. O Pão que eu darei. O Sacramento da Eucaristia, São Paulo: Paulinas, 1999 (Título Original): Il Pane che io darò Roma: Edizioni Borla, 1993

ROBEYNS A. Les Droits des Baptisés dans l'Assemblée Liturgique, in $L M D$ 61 (1960), 97-130

SCHELESINGER, H. \& PORTO, H. Sacrifício, in Dicionário Enciclopédico das Religiões, Vol II, Petrópolis: Vozes, 1995, 2261-2264

SCHNACKENBURG, R. Sacrifício, in BAUER, J. B. Dicionário de Teologia Bíblica, Vol II, São Paulo: Loyola, 1978, 1027-1035

SCHENEIDER, T. \& HILBERATH, B. J. Sacrificio, in EICHER, P. (dir.), Dicionario de Conceptos Teologicos, Vol II, Barcelona: Editorial Herder, 1990, 431-439

VATICANO II. Constituição «Sacrosanctum Concilium», in Compêndio do Vaticano II, Constituições, Decretos, Declarações, Petrópolis: Vozes, $1968,257-306$

VERHEUL, Ambroos. A Estrutura Fundamental da Eucaristia, São Paulo: Paulinas, 1982

VIDAL, J. Sacrificio, in POUPARD P. (dir.), Dicionário de las Religiones, Barcelona: Editorial Herder, 1987, 1561-1565

Pe. Valeriano dos Santos Costa é Doutor em Liturgia pelo Pontifício Ateneo Santo Anselmo, Roma e professor de Liturgia na Pontificia Faculdade de Teologia Nossa Senhora da Assunção, São Paulo - SP. 